\section{Mobbing og fremtidig helse}

Mobbing er forbundet med flere sosiale, psykologiske og helsemessige aspekter, men det å mobbe i ung alder ga lavere økning av nivået av C-reaktivt protein (CRP) senere i livet, ifølge en studie fra North Carolina, USA.

I underkant av 1500 barn i alderen 9-16 år ble inkludert i en prospektiv, longitudinell studie, der deres forhold til mobbing ble kartlagt ved bruk av et strukturert intervju. Samtidig ble det tatt flere blodprøver for måling av C-reaktivt protein (CRP), som øker i blodkonsentrasjon ved inflammatorisk respons. Omtrent $60 \%$ av deltakerne ble fulgt opp ved 19-21 års alder med nye CRP-målinger.

CRP-nivåene steg hos alle barna, uavhengig om de var mobbere, mobbeofre eller ingen av delene. Å bli mobbet var forbundet med større økning av CRP-nivået, mens det å være mobber var forbundet med mindre økning enn hos de barna som ikke var involvert i mobbing. Sammenhengen forble signifikant etter justering for kroppsmasseindeks, rusmisbruk og mål for fysisk og mental helse.

- Denne studien viser hvor tett sammenhengen mellom kropp og sinn er og hvordan CRP-nivået kan endre seg med grad av mobbing, sier Lars Lien, leder for Nasjonalt kompetansetjeneste for samtidig rusmisbruk og psykisk lidelse, Sykehuset Innlandet, og professor ved Høgskolen i Hedmark.

- Det nye med denne studien er at det å mobbe ser ut til å ha en beskyttende effekt på lavgradig inflammasjon målt ved CRPnivå. Dette er ikke påvist tidligere, og det kan knyttes mot den samme effekten som ses ved å ligge på et høyt sosioøkonomisk nivå eller, for mobberens del, å være «øverst på rangstigen», sier Lien.

- Styrken ved studien er at den er prospektiv, med en rekke måletidspunkter både for mobbing og CRP-nivå, og at CRP-nivået også er målt før mobbingen startet. Svakhetene er at relativt få deltakere mobbet eller ble mobbet. Derfor var det ikke mulig å gjøre analyser på undergrupper knyttet til kjønn, alder, genetikk etc. Det er viktig å gjøre flere studier på undergrupper og foreta grundigere analyser av inflammasjon $i$ form av cytokiner og se det $i$ sammenheng med genetiske forhold, sier Lien.

\section{Tor Atle Rosness}

Tidsskriftet

\title{
Årsaker til mødredødsfall
}

\section{Dødsfall i forbindelse med graviditet og fødsel er fortsatt utbredt i mange} land, men årsaker og forekomst varierer mellom ulike regioner.

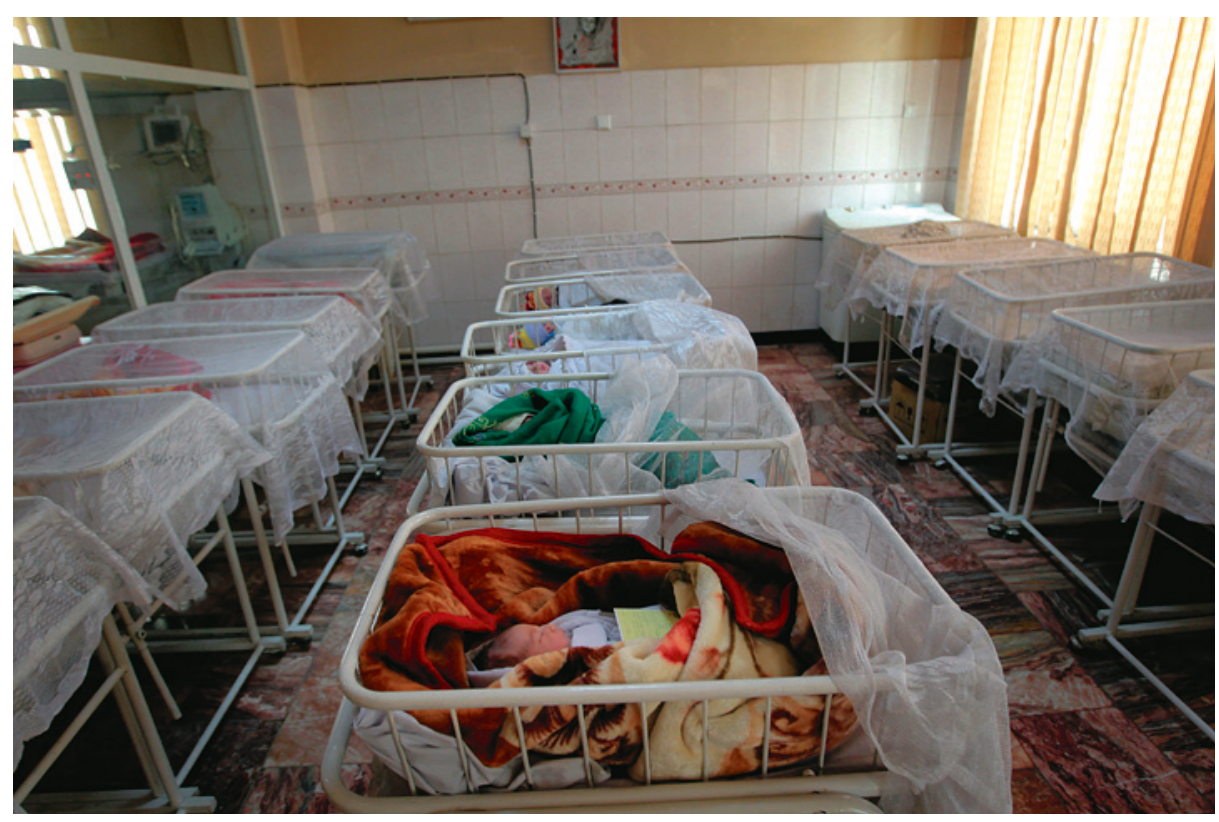

Illustrasjonsfoto: Behrouz Mehri/NTB scanpix

I en systematisk oversiktsartikkel er årsaker til mødredødsfall i perioden 2003-09 analysert. Artikkelen er basert på 417 datasett fra 115 land. Mødredødelighet og fordeling av dødsårsak på verdensbasis er estimert utfra 60799 inkluderte dødsfall.

Forekomsten av mødredødsfall på verdensbasis ble beregnet til 2,4 millioner i studieperioden. Nær $73 \%$ skyldtes direkte årsaker som blødning, hypertensjon og sepsis, mens de resterende dødsfallene skyldtes indirekte årsaker som hivinfeksjon, epilepsi og selvmord.

Blødning forårsaket $27,1 \% \quad 195 \% \mathrm{KI}$ 19,9-36,2) av mødredødsfallene og var hyppigste dødsårsak $\mathrm{i}$ alle regionene. I LatinAmerika og Karibia skyldtes $22,1 \%$ av dødsfallene hypertensive tilstander, mens det på verdensbasis var $14,0 \%$. Nesten alle dødsfall relatert til sepsis fant sted i lavinntektsland, og høyest andel ble funnet i Sør-Asia med $13,7 \%$ av dødsfall i regionen. I Afrika sør for Sahara var $6,4 \%$ av dødsfallene forårsaket av hivinfeksjon, og samme region hadde flest mødredødsfall i verden $\mathrm{i}$ alle kategorier av dødsårsaker.

- Det er tankevekkende at de fleste mødre- dødsfall fortsatt skyldes tilstander som kan forebygges eller behandles, sier seniorforsker Siri Vangen ved Nasjonal kompetansetjeneste for kvinnehelse. - Blødning var den hyppigste dødsårsaken i alle regioner. Placentakomplikasjoner knyttet til arr i livmoren etter tidligere keisersnitt spiller en økende rolle her.

- Foruroligende mange kvinner dør også av hypertensive svangerskapskomplikasjoner. Videre synes en reorientering mot forebygging og behandling av kronisk sykdom som hjerte- og karsykdom, kreft, diabetes og luftveissykdommer å være nødvendig i alle regioner. Selv om vi har lav mødredødelighet, er dette aktuelle problemstillinger også i Norge. Videre er styrking av kvinners posisjon sentralt for å utjevne regionale forskjeller i forekomst av mødredødelighet, sier Vangen.

\section{Matilde Risopatron Berg}

Sykehuset Innlandet, Hamar

Litteratur

1. Say L, Chou D, Gemmill A et al. Global causes of maternal death: a WHO systematic analysis. Lancet Glob Health 2014; 2: e323-33.

\section{Litteratur \\ 1. Copeland WE, Wolke D, Lereya ST et al. Childhood bullying involvement predicts low-grade systemic inflammation into adulthood. Proc Natl Acad Sci} U S A 2014: 111: 7570-5. 